\title{
IDENTIFIKASI PERUBAHAN MORFOLOGI SEL Aeromonas hydrophila TERHADAP PAPARAN EKSTRAK DAUN MANGROVE Rizophora mucronata
}

\author{
Mikchaell A.P. Panjaitan ${ }^{a^{*}}$, Eddy Suprayitno ${ }^{a} \operatorname{Hardoko}^{a}$ \\ ${ }^{a}$ Fakultas Perikanan dan Ilmu Kelautan Universitas Brawijaya, \\ Jl. Veteran, Kota Malang, Indonesia \\ *Koresponden penulis: mikchaell_thp@ub.ac.id
}

\begin{abstract}
Abstrak
Penelitian ini bertujuan untuk mengidentifikasi perubahan morfologi sel A. hydrophila menggunakan scanning electron microscopy dan mengetahui senyawa antibakteri dari R. mucronata. Prosedur penelitian meliputi ekstraksi, uji aktivitas antibakteri, uji total fenol, SEM dan LC-MS. Hasil penelitian menunjukkan peningkatan aktivitas antibakteri pada ekstrak daun R.mucronata yang telah dimurnikan. Uji total fenol menunjukkan peningkatan total fenol dari ekstrak kasar sebesar 7,13 $\pm 0,04 \%$ menjadi 8,55 $\pm 0,03 \%$ dalam ekstrak fraksi metanol. Kerusakan sel A. hydrophila akibat paparan ekstrak daun R. mucronta diamati dengan uji SEM. Hasil uji menunjukkan bahwa ada kerusakan sel yang disebabkan oleh paparan ekstrak (pemanjangan ukuran sel, pembengkakan atau pengembungan sel, dan pembentukan lubang pada permukaan dinding sel). Uji LC-MS mendeteksi chlorogenic acid terkandung dalam ekstrak R.mucronata, yang diketahui bersifat antibakteri.
\end{abstract}

Kata kunci : asam klorogenat, senyawa fenolik, SEM

\begin{abstract}
This study aims to identify the cell morphology changes of A. Hydrophila using scanning electron microscopy and to investigate the antibacterial compound from $R$. mucronata. The research procedure includes extraction, antibacterial activity test, total phenol test, total phenol test, SEM and LC-MS. The results showed an increase of antibacterial activity in purified R.mucronata leaf extract The total phenol test figured an increase in the total phenol of the crude extract from $7.13 \pm 0.04 \%$ to $8.55 \pm 0.03 \%$ in the spread methanol fraction extract. The cell damage of $A$. Hydrophila resulting from exposure to $R$. mucronta leaf extract was observed by the SEM test. It describes that there is come cellular damage caused by the exposure of extract (the lengthening of cell size, swelling or cellular bloat, and the formation of holes on the cell wall surface). The LC-MS detected chlorogenic acid contained in the extract of $R$. mucronata, known as antibacterial.
\end{abstract}

Keywords : chlorogenic acid, phenolic compounds, SEM

\section{PENDAHULUAN}

Rhizophora mucronata merupakan salah satu jenis mangrove yang diketahui memiliki senyawa bioaktif mulai dari akar, batang, bunga, buah, dan daun. Senyawa bioaktif tersebut berasal dari hasil metabolit sekunder seperti saponin [1], alkaloid [2] dan flavonoid [3] yang masuk kedalam senyawa fenolik. Senyawa fenolik diketahui berpotensi menjadi agen antibakteri dengan cara merusak struktur protein pada membran sel bakteri yang menyebabkan lisis nya sel bakteri [4]. Selain itu senyawa tersebut dapat merusak stabilitas dan fluiditas membran fosfolipid bilayer bakteri [5]. Penelitian ini bertujuan untuk mengamati perubahan morfologi sel $A$. Hydrophila terhadap paparan ekstrak $\mathrm{R}$. mucronata dan mengidentifikasi senyawa yang berpotensi sebagai antibakteri dari $R$. mucronata.

\section{MATERI DAN METODE}

\section{Materi Penelitian}

Daun $R$. mucronata yang digunakan dalam penelitian ini merupakan daun yang masih menempel pada pohon dan berwarna hijau segar dengan panjang daun 10-15 cm. 
Sampel kemudian dikeringkan dan dihaluskan hingga berbentuk serbuk.

\section{Ekstraksi and Fraksinasi}

Proses ekstraksi daun R.mucronata dilakukan dengan maserasi menggunakan pelarut metanol. Perbandingan pelarut dan serbuk yaitu 1:2 [6]. Filtrat yang diperoleh kemudian dipekatkan menggunkan Rotary evaporator pada suhu $40^{\circ} \mathrm{C}$ [7]. Ekstrak kasar kemudian difraksinasi dengan pelarut etil asetat dan n-heksan. Fraksinasi dilakukan dengan metode corong pisah yang bertujuan untuk memurnikan senyawa dalam ekstrak dengan cara menarik senyawa lain yang memiliki kepolaran berbeda [8]. Sejumlah ekstrak dimasukkan kedalam corong pemisah dan ditambahakan pelarut n-heksan dan etil asetat kemudian dikocok perlahan. Corong pemisah didiamkan beberapa saat sampai terbentuk dua lapisan. Setelah itu kedua lapisan tersebut dipisahkan dengan cara mengalirkan melalui kran dan di uapkan pada suhu $40^{\circ} \mathrm{C}$ sampai kering.

\section{Uji Aktivitas Antibakteri}

Uji Aktivitas antibakteri dilakukan menggunakan metode difusi cakram [9,6]. A. hidrophila dikultur dalam $10 \mathrm{ml}$ media Agar Miring TSA dan diinkubasi selama 24 jam pada suhu $37^{\circ} \mathrm{C}$. Uji aktivitas antibakteri dimulai dengan mengambil bakteri uji dengan menggunakan Cotton swab steril dan disebar di permukaan media agar miring TSA pada cawan petri kemudian diberi kertas cakram yang telah direndam dalam ekstrak dan di aplikasikan di media agar miring TSA pada cawan petri yang berisi bakteri uji. Sampel diinkubasi selama 24 jam pada suhu $37^{\circ} \mathrm{C}$ [6]. Zona hambat merupakan daerah zona bening dikurangi diameter cakram.

\section{Uji Total Fenol}

Uji total fenol dilakukan untuk mengetahui senyawa fenol pada ekstrak kasar dan ekstrak fraksi. Pengujian total fenol daun $R$. mucronata dilakukan dengan metode spektrofotometri menggunakan pereaksi asam sulfanilat.

Identifikasi kerusakan sel $A$. hydrophila
Uji SEM dilakukan untuk melihat pengaruh ekstrak daun mangrove terhadap sel A. Hydrophila. Senyawa fenol yang terkandung di dalam sampel diduga berperan dalan aktivitas antibakteri yang dimiliki oleh R. Mucronata. Senyawa fenol diketahui bersifat antibakteri dengan cara merusak stabilitas dan fluiditas dari membran fosfolipid bilayer [5,10]. Uji ini dilakukan dengan 2 perlakuan yang berbeda yaitu tanpa pemberian ekstrak (4 mL suspensi bakteri 1x24 jam) dan dengan pemberian ekstrak fraksi metanol (2 $\mathrm{mL}$ suspensi bakteri 1x24 jam ditambah dengan $2 \mathrm{~mL}$ ekstrak fraksi metanol) sehingga dapat dideteksi kerusakan yang terjadi pada A.hydrophila yang diakibatkan oleh pemberian ekstrak fraksi metanol.

\section{Identiikasi senyawa antibakteri}

LC-MS digunkaan untuk mengidentifikasi senyawa yang berpotensi sebagai antibakteri. Analisis LC-MS dilakukan pada ekstrak yang memiliki aktifitas antibakteri paling baik sebanyak $5 \mathrm{~g}$. Pengujian LC-MS dengan cara pemisahan campuran berdasarkan perbedaan kecepatan perambatan komponen dalam medium tertentu. Komponen tersebut akan dipisahkan antara fase diam dan fase gerak. Pemisahan komponen sampel dengan cara melewatkan sampel pada kolom yang kemudian diukur kadar tiap komonen menggunakan detector MS (Mass Spectometry) [11].

\section{HASIL DAN PEMBAHASAN}

\section{Uji Aktivitas Antibakteri Ekstrak Daun $\boldsymbol{R}$. Mucronata}

Uji aktivitas antibakteri dilakukan dengan menggunakan 2 sampel yaitu ekstrak kasar dan ekstrak fraksi metanol. Dari hasil zona hambat yang terbentuk diketahui bahwa ekstrak kasar memiliki zona habat $(6,5 \pm 0.58 \mathrm{~mm})$ lebih kecil daripada ekstrak fraksi metanol $(7,1 \pm 0.2$ $\mathrm{mm})$. Hal tersebut menunjukkan bahawa proses pemurnian senyawa yang dilakukan meningkatkan aktivitas antibakteri dari daun R. mucronata.

\section{Total Fenol}

Pengukuran total fenol bertujuan untuk mengetahui kadar senyawa fenol yang terkandung dalam kedua jenis ekstrak. 
Kandungan total fenol pada ekstrak kasar dengan pelarut metanol sebesar 7,13 $\pm 0.04 \%$, sedangkan pada ekstrak fraksi metanol sebesar $8.55 \pm 0.03 \%$. hasil uji menunjukkan bahwa kandungan fenol dalam ekstrak kasar mengalami peningkatan setelah dilakukan proses pemurnian dengan corong pisah. peningkatan total kandungan fenol dalam ekstrak diduga berperan dalam peningkatan kemampuan hambat terhadap pertumbuhan A. hydrophila. Mekanisme kerja antibakteri
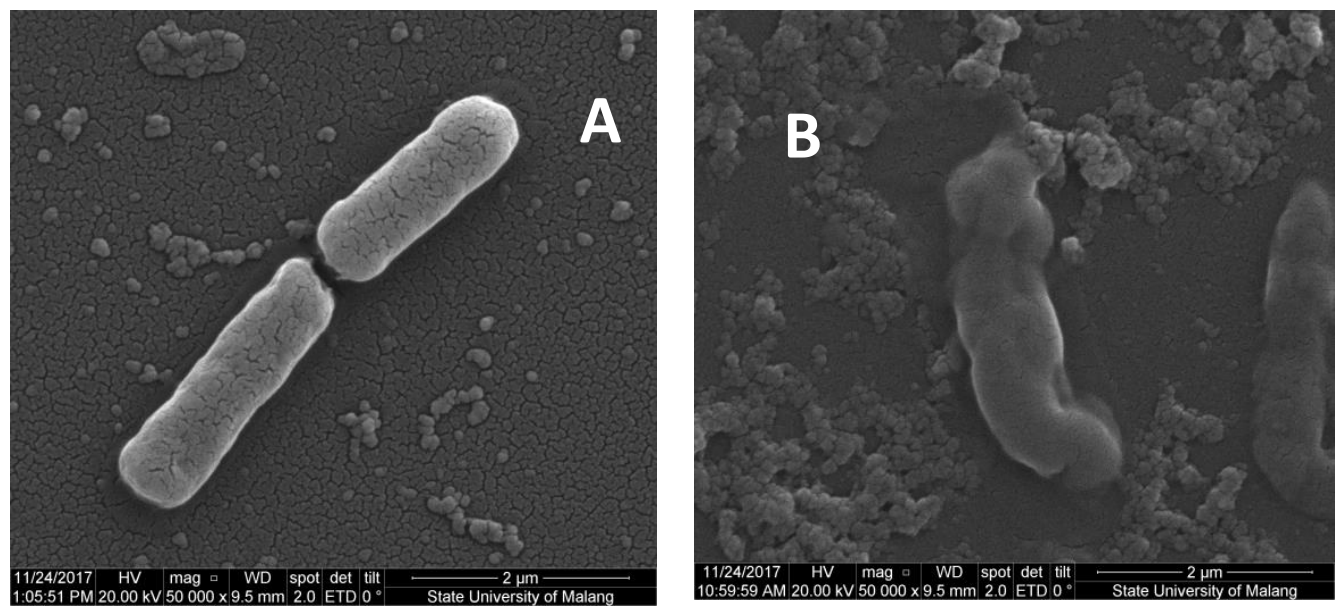

senyawa golongan fenol yaitu dengan cara inaktivasi protein pada membrane sel [12] [13]. Selain itu beberapa senyawa golongan fenol yang berikatan dengan protein dapat menyebabkan struktrur protein seperti dinding sel maupun membrane sel menjadi rusak. Hal tersebut menyebabkan terganggunya fungsi permeabilitas selektif, pengangkutan aktif dan pengendalian susunan protein yang mengakibatkan lisisnya sel bakteri [4].

Gambar 1. Kerusakan sel A. hydrophila dilihat menggunakan SEM (50.000x). A : tanpa perlakuan (kontrol), B : sel terpapar ekstrak

\section{Pengamatan kerusakan sel $A$. hydrophila}

Pengamatan kerusakan sel A. hydrophila menggunakan SEM bertujuan untuk melihat pengaruh senyawa yang terkandung dalam ekstrak terhadap sel A. hydrophila.. Hasil pengamtan kerusakan sel $A$. hydrophila dapat dilihat pada Gambar 1.

Hasil pengamatan kerusakan sel $A$. hydrophila menunjukkan bahwa pada sel bakteri tanpa perlakuan pemberian ekstrak memiliki bentuk sel yang tetap utuh (berbentuk batang), sedangakan sel pada bakteri dengan perlakuan pemberian ekstrak mengalami kerusakan (cenderung berbentuk bundar serta lebih pendek). Pada perlakuan pemberian ekstrak terjadi pemanjangan ukuran sel. Menurut Wang and Johson (1992), terjadinya pemanjangan ukuran sel mengindikasikan adanya kerusakan sel [14]. Kerusakan lainnya 
Tabel 1. Hasil LC-MS ekstrak fraksi metanol daun R. mucronata

\begin{tabular}{cccc}
\hline Retention Time & Molecular Mass & Molecular Formula & Compound \\
\hline 3.101 & 163.0394 & $\mathrm{C}_{9} \mathrm{H}_{6} \mathrm{O}_{3}$ & 3-hydroxycoumarin \\
\hline 3.101 & 355.1031 & $\mathrm{C}_{6} \mathrm{H}_{18} \mathrm{O}_{9}$ & Chlorogenic acid \\
\hline 5.93 & 209.1545 & $\mathrm{C}_{13} \mathrm{H}_{20} \mathrm{O}$ & $\beta$-lonone \\
\hline 10.90 & 284.2966 & $\mathrm{C}_{18} 8 \mathrm{H}_{37} \mathrm{NO}$ & Stearamide \\
\hline
\end{tabular}

Berdasarkan hasil uji LC-MS didapatkan bahwa senyawa yang diduga memiliki aktivitas antibakteri yaitu chlorogenic acid. Senyawa chlorogenic acid merupakan senyawa fenolik alami yang juga ditemukan pada buah apricot (Prunus Armeniaca L.), biji kopi hijau serta daun teh. Senyawa ini diketahui memiliki aktivitas antibakteri, antioksidan, antivirus, dan anti diabet [18,19,20,21,22].

Senyawa chlorogenic acid menunjukkan aktivitas antibakteri terhadap bakteri gram negatif dengan bentuk sel rod-shape seperti $E$. coli, Salmonella enteritidis, pseudomonas flourescens [19]. Bakteri A. Hydrophila diketahui merupakan bakteri gram negatif dengan bentuk sel rod shape. Hal tersebut menunjukkan bahwa senyawa chlorogenic acid diindikasikan mampu menghambat bakteri gram negatif dengan bentuk sel rod shape dengan cara berikatan dengan membran luar sel, merusak membrane, mengganggu intrasel dan melepaskan makromolekul sitoplasma, yang beujung pada kematian sel [21].

\section{KESIMPULAN}

Berdasarkan hasil penelitian dapat disimpulkan bahwa :

1. Terjadi perubahan morfologi sel A.hydrophila seperti pembengkakan atau penggembungan sel dan terbentuknya lubang-lubang pada permukaan dinding sel.

2. Uji LC-MS menunjukkan ekstrak R.mucronata mengandung senyawa chlorogenic acid yang diketahui bersifat antibakteri.

\section{DAFTAR PUSTAKA}

[1] Mahato, S.B., Sarkar, S.K and Poddar, G. 1988. Triterpenoid saponins. Phytochemistry 27 : 3037-3067.

[2] Gurudeeban, S, Ramanathan, T, and Satyavani, K. 2013. Antimicrobial and
Radical Scavenging Effet of Alkaloid Extracts from Rhizophora mucronata.

[3] Nurdiani, R, Firdaus, $M$ and Awaludin, A. 2012. Phytochemical Screening and Antibacterial Activity of Methanol Extract of Mangrove Plant (Rhizophora mucronata) from Porong River Estuary. Journal Basic Science And Technology, 1 (2), 27-29, 2012 ISSN : 2089-8185.

[4] Susanti, A. 2008. Daya Antibakteri Ektrak Etanol Daun Beluntas (Pluchea indicaless) Terhadap Escherichia coli secara In Vitro. Jurnal Universitas Airlangga Vol 1. No 1.

[5] Tarahovsky, Y., Kim, Y.A., Yagolnik, E.A., Muzafarov, E.N. 2014. Flavonoid membrane interactiona : Involvement of flavonoid-metal complexes in raft signaling. Biochimica et Bhiophysica Acta (BBA)- Biomembranes Volume $1838: 1235-1246$.

[6] Ravikumar, S., Granadesign, M., Suganthi, P., and Ramalakshmi, A. 2010. Antibacterial potential of Chosen Mangrove Plants Against Isolated Urinary Tract Infectious Bacterial Pathogens. International Journal of Medicine and Medical Sciences. Vol 2 No 3 : 94-99.

[7] Lim, C. J., Basri, M., Lian, G.C Omar, D. 2017. Phytoinhibitory activities and ectraction optimalizion of potent invasive plants as eco-friendly weed suppressant against Echinochloa (L.) Link. Industrial Crops and Products 100 : 19-34.

[8] Hardoko, Sasmito, B.S., Puspitasari, Y.E. 2016. Antidiabetic and Antioxidant Activities of Tannin Extract of Rizophora mucronata Leaves. Journal of Chemical and Pharmaceutical Research Vol. 8 No. 3:143-148 
[9] Kim, J., Marshall M.R., Wie, C. 1995. Antibacterial activity of some essential oil components against five food born pathogens. J. Agric. Food Chem. 43: 2839-2845

[10] Mulyani, Y., Bachtiar, E., dan Kurnia, M.U. 2013. Peranan Senyawa metabolit sekunder tumbuhan mangrove terhadap infeksi bakteri Aeromonas hydrophyla pada ikan mas (Cyprinus carpio L.). Jurnal Akuatika Vol. IV No. 1. ISSN 0853-2523

[11] Vogeser, M. And Seger, C. 2008. A Decade of HPLC-MS/MS In the Routine Clinical Laboratory Goals for Futher Development. Clinical Biochemistry. 41 : 649-662.

[12] Singh, I.P., Bharate, S.B. 2005. Anti-HIV Natural Products. Journal Current Science Vol. 89 No. 2 : 269-290

[13] Ko, W.W., Chiang, S.R., Lee, H.C., and Chuang, Y.C. 2003. In Vitro and In Vivo Activities Of Fluoroquinoloness Against Aeromonas hydrophila Antimicrobial Ageneted Chemotherapy. Journal Clinic Microbial May 47 :2217-2222.

[14] Wang, L.L and Johnson, E.A. 1992. Inhibition of Listeria monocytogenes by Fatty Acids and Monoglycerides. Applied and environmental microbiology Vol 58 No. 2 : 624-629.

[15] Asriani, Laksmi, B.S., Yasni, S., Sudirman, I. 2007. Mekanisme Antibakteri metabolit Lb. Plantarum kik dan Monoasilgliserol minyak kelapa terhadap bakteri pathogen pangan. Jurnal Teknologi Dan Industri Pangan Vol. XVIII No. 2 : 126-133

[16] Jawetz, E. Melnick J.L. and Adelberg, E.A. 2001. Mikrobiologi Kedokteran (Medical Microbiology) Edisi 20. EGC, Jakarta.

[17] Nursidika, P., Saptarini, O., Rafiqua, N. 2014. Aktivitas Antimikrob Fraksi Etanol Buah Pinang (Areca catechu L) Pada Bakteri Methicilin Resistant Staphylococcus aureus. MKB Vol $46 \mathrm{No}$ 2.
[18] Zhang, J.S., Zang, J.J., Wu, N., Li, J., Wang. 2013. Separation and purification of chlorogenic acid from Lonicera japonica Thunb. Leaves exact with macroporous resins. J.Med. Plant Res. Vol 7 No. 24 : 1784-1792

[19] Mujtaba, A., Masud, T., Ahmad, A., Ahmed, W., Jabbar, S., Levin, R.E. 2017. Antibacterial Activity by Chlorogenic acid Isolated Through Resin From Apricot (Prunus Armeniaca L.) Pakistan Journal of Agricultural Research. Vol 30 Issue 2 : 144-148.

[20] Farah, A., Monteriro, M., Donangelo, C.M., Lafay, S. 2008. Chlorogenic Acids from Green Coffee extract are highly bioavailable in humans. The Journal of Nutrition Vol 138 No. 12 : 2309-2315

[21] Lou, Z., Wang, H., Zhu, S., Ma, C. Wang, Z. 2011. Antibacterial Activity and Mechanism of Action of Chlorogenic Acid. Journal of Food Science. Vol 76. No 6.

[22] Kabir, F. Katayama, S., Tanji, N., Nakamura, S. 2014. Antimicrobial effects of chlorogenic acid and related compounds. J Korean Soc Appl Biol Chem Vol. 57 No. 3 : 359-365 